\title{
YIELD OF VARIETIES OF CUCURBITA PEPO PREIMMUNIZED WITH MILD STRAINS OF PAPAYA RINGSPOT VIRUS - TYPE W AND ZUCCHINI YELLOW MOSAIC VIRUS
}

\author{
Estela Bonilha ${ }^{1}$; Ricardo Gioria ${ }^{2}$; Rômulo Fujito Kobori²; Paulo Tarcísio Della Vecchia ${ }^{2}$; Sônia \\ Maria de Stefano Piedade; ${ }^{3}$ Jorge Alberto Marques Rezende ${ }^{4 *}$ \\ ${ }_{2}^{1}$ USP/ESALQ - Programa de Pós-Graduação em Fitopatologia. \\ ${ }^{2}$ Sakata Seed Sudamerica LTDA - C.P. 427 - 12906-840 - Bragança Paulista, SP - Brasil. \\ ${ }^{3}$ USP/ESALQ - Depto. de Ciências Exatas - C.P. 09 - 13418-900 - Piracicaba, SP - Brasil. \\ ${ }^{4}$ USP/ESALQ - Depto. de Entomologia, Fitopatologia e Zoologia Agrícola - C.P. 09 - 13418-900 - Piracicaba, SP - \\ Brasil. \\ *Corresponding author<jamerezen@esalq.usp.br>
}

ABSTRACT: Papaya ringspot virus - type W (PRSV-W) and Zucchini yellow mosaic virus (ZYMV) are the most prevalent viruses in cucurbit crops in Brazil and responsible for frequent yield losses. Diseases caused by these viruses are difficult to control. The objective of this work was to evaluate the effects of mild strains PRSV-W-1 and ZYMV-M on the yield of Cucurbita pepo L. cvs. Samira, Novita Plus, AF 2847, and Yasmin, under plastic greenhouse and field conditions. Plants infected with ZYMV-M and grown in a plastic greenhouse did not exhibit typical leaf symptoms or significant alterations in quantitative and qualitative fruit yield. However, when infected with PRSV-W-1, or PRSV-W-1 + ZYMV-M, the plants exhibited severe leaf mosaic symptoms and reduced fruit quality, although there were no changes in the number and mean fruit weight harvested from these plants. When these plants were infected with PRSV-W-1 and studied simultaneously in the field and plastic greenhouse, intensification of symptoms in the fruits and leaves was more pronounced under the greenhouse conditions. Quantitative yield did not change. Environmental factors seem to influence symptoms induced by PRSV-W-1.

Key words: control, potyvirus, cross protection, cucurbitaceae

\section{PRODUÇÃO DE VARIEDADES DE CUCURBITA PEPO PREMUNIZADAS COM ESTIRPES FRACAS DO PAPAYA RINGSPOT VIRUS - TYPE W E DO ZUCCHINI YELLOW MOSAIC VIRUS}

RESUMO: O Papaya ringspot virus - type W (PRSV-W) e o Zucchini yellow mosaic virus (ZYMV) são os vírus predominantes em culturas de cucurbitáceas no Brasil, onde geralmente causam danos significativos na produção. As doenças causadas por ambos os vírus são de difícil controle. $\mathrm{O}$ objetivo desse trabalho foi avaliar o efeito das estirpes fracas PRSV-W-1 e ZYMV-M na produção de abobrinha de moita (Cucurbita pepo L. cvs. Samira, Novita Plus, AF 2847, and Yasmin) em condições de estufa plástica e de campo. Plantas infectadas com a estirpe ZYMV-M sob condições de estufa plástica não exibiram sintomas foliares típicos da doença e alterações na quantidade e qualidade dos frutos produzidos. No entanto, quando infectadas com a estirpe PRSV-W-1, ou PRSV-W-1 + ZYMV-M, as plantas mostraram sintomas severos de mosaico foliar e redução na qualidade dos frutos. Não houve alteração no número e no peso médio dos frutos colhidos dessas plantas. Quando as plantas dessas variedades foram infectadas com a estirpe PRSV-W-1 e avaliadas simultaneamente em campo e em estufa plástica, constatou-se que a intensificação de sintomas foi mais pronunciada sob condições de estufa plástica. A produção quantitativa não foi alterada. Fatores ambientais parecem ter influenciado a intensificação dos sintomas induzidos pela estirpe PRSV-W-1.

Palavras-chave: controle, potyvirus, proteção, cucurbitaceae 


\section{INTRODUCTION}

Papaya ringspot virus - type W (PRSV-W) and Zucchini yellow mosaic virus (ZYMV) are species taxonomically classified as belonging to the genus Potyvirus, in the Potyviridae family. They are easily transmitted by various species of aphids, with a nonpersistent, non-circulative virus-vector relationship (Purcifull et al., 1984; Desbiez \& Lecoq, 1997). These two viruses, either individually or in mixed infections, cause damage in many cucurbit species, which is generally higher in zucchini squash cultivars (Cucurbita pepo L.), due to the high sensitivity of these plants to these potyviruses. Symptoms induced by both viruses generally include mosaic, reduced and malformed leaves, plant stunting and fruit malformation accompanied by a green darkening of the skin.

Control of these viruses is difficult in squash and other cucurbits. Available sources of resistance have not yet been incorporated into all zucchini cultivars, or the resistance incorporated is not enough to provide effective control of these viruses. Attempts to control both viruses by chemical controlling the insects or via cultural practices that minimize the incidence of these viruses have proven ineffective. Preimmunizing plants with mild strains of virus may help protect them against infection and/or effects of severe isolates of the virus in the field while not affecting plant yield. The use of squash plants preimmunized with mild strains of the viruses has been investigated for more than ten years in Brazil, and has proven effective in controlling PRSV-W and ZYMV in some cucurbit species, especially C. pepo cv. Caserta (Rezende \& Pacheco, 1998; Rezende et al., 1999; Dias \& Rezende, 2000).

The preimmunization of zucchini squash with mild strains of PRSV-W and ZYMV has been studied only on the cultivar Caserta. The effect of these protective mild strains needs to be evaluated on widely grown susceptible squash cultivars using both single and double inoculations. Therefore, the objective of this study was to evaluate the effect of the protective mild strains PRSV-W-1, selected by Rezende et al. (1994), and ZYMV-M, obtained by Rabelo \& Rezende (2004), in single and mixed inoculations, on yield and marketability of four commercial cultivars of C. pepo.

\section{MATERIAL AND METHODS}

Seedlings of $C$. pepo cvs. Novita Plus, Samira, AF 2847, and Yasmin were produced in styrofoam trays containing pine bark media, with one seed sown per cell. PRSV-W-1 and ZYMV-M inocula were obtained from infected zucchini squash leaves ground in potassium phosphate buffer $(0.02 \mathrm{M}, \mathrm{pH} 7.0)$, containing $0.02 \mathrm{M}$ sodium sulfite $(1: 10, \mathrm{w} / \mathrm{v})$. Inoculations were made mechanically on the squash cotyledons that were previously sprinkled with silicon carbide abrasive (Carborundum) and then rubbing with cotton moistened in the inoculum solution. Infection by both mild strains was confirmed by PTA (Plate Trapped Antigen) ELISA (Enzyme-linked Immunosorbent Assay) (Mowat \& Dawson, 1987), using specific polyclonal antisera against the PRSV-W and ZYMV, 20 days after inoculation.

The effect of PRSV-W-1 and ZYMV-M on the yield of these zucchini squash cultivars was evaluated in plastic greenhouses, in Bragança Paulista, State of São Paulo, Brazil (22057’07" S; 46³2’31" W; 817 m above sea level). The following treatments were compared between the four zucchini cultivars: (i) plants infected with PRSV-W-1; (ii) plants infected with ZYMV-M; (iii) plants infected with both PRSV-W-1 and ZYMV-M; (iv) non-inoculated plants. The experiment was set up as a $4 \times 4$ factorial treatment arrangement in a randomized complete block design with four replicates. Six plants were evaluated per plot. Interaction of each cultivar and treatment was evaluated in isolated plastic greenhouses. Squash plants were transplanted the day after inoculation into soil located in plastic greenhouses on September 3, 2004.

Weights of total fruits and marketable fruits per plant, mean fruit weight per plant, fruit quality and leaf symptoms were evaluated. Fruit quality and leaf symptoms were rated on a scale of 1 to 5. Symptom free fruits were rated 1; deformed fruits with intense skin color alterations were rated 5; and intermediate ratings $(2,3$, and 4$)$ were attributed according to the intensity of symptoms. Fruits rated 2 to 5 were classified as unmarketable. Plants without mosaic symptoms were rated 1; plants with mild mosaic and no leaf deformation were rated 2; plants with severe mosaic, intense leaf deformation and blisters were rated 5; and plants with intermediate mosaic symptoms were rated 3 to 4 . Fifteen harvests were obtained from October 11 to November 11, 2004. Fruits from each plant were harvested and weighed separately.

Using the same zucchini squash cultivars as in the previous experiment, the effect of PRSV-W-1 on fruit yield under greenhouse and field conditions was evaluated from September 12 to November 11, 2005, at the same location. The experiment was set up as a $2 \times 4$ factorial treatment arrangement in a randomized complete block design with three replications. Four plants were evaluated per replication. Two treatments were simultaneously compared in the field and plastic greenhouse: (i) plants infected with PRSV-W-1; and (ii) non-inoculated plants. Evaluations followed the 
same criteria adopted in the previous experiment. Fruit harvest began on October 17 and ended on November 11, 2005, with a total of ten harvests.

All yield data were analyzed using SAS statistical system, and the statistical means were compared using Tukey's test $(p=0.05)$.

\section{RESULTS AND DISCUSSION}

In general, plants of all cultivars infected with ZYMV-M did not show a great reduction on the total fruit yield (Table 1). The yield of unmarketable fruits was $8.1 \%$ for Samira, $21.6 \%$ for Novita Plus, 31.2\% for AF-2847, and 35.7\% for Yasmin. On the other hand, the yield of unmarketable fruits of plants from all cultivars infected with PRSV-W-1 and its mixture with ZYMV-M varied from 65\% (AF-2847/PRSV-W1) to $100 \%$ (Yasmin/PRSV-W-1). Infection with PRSV-W-1 alone and combined with ZYMV-M also caused severe mosaic symptoms on all plants, while plants infected with ZYMV-M alone presented, as expected, milder leaf symptoms. However, single or mixed infection with these mild strains did not affect fruit size (mean weight), which was similar to that of non-inoculated plants for all cultivars. Percentage of unmarketable fruits in non-inoculated plants was 7.9\% for Samira, $18.6 \%$ for Novita Plus, $13.4 \%$ for $\mathrm{AF}$ 2847 , and $18.7 \%$ for Yasmin.

Harvests of fruits produced by cvs. Samira, Novita Plus, AF 2847, and Yasmin infected with PRSV$\mathrm{W}-1$ were concluded simultaneously in the field and plastic greenhouses when healthy plants in the field began to present evident symptoms of natural viral infection.

Total fruit weight in cvs. Samira, AF 2847, and Yasmin did not differ between treatments (Table 2). Only plants of cv. Novita Plus infected with PRSVW-1 and maintained in the plastic greenhouse showed smaller fruit yield. Once more the yield of unmarketable fruits was more evident for PRSV-W-1 infected plants grown in the plastic greenhouse, with the greatest percentage of such fruits harvested from cv. Yasmin $(60.2 \%)$. One exception was the high percentage of unmarketable fruits produced by PRSV-W-1 infected Samira in the field (50.7\%). However, during this growth season the apparent effect of the greenhouse condition on the quality of fruits harvested from PRSV-W-1 infected plants was not as accentuated as it was in the previous experiment (Figure 1).

Table 1 - Weight of total fruits and marketable fruits per plant, mean fruit weight, mean rating of symptoms in fruits and leaves of zucchini squash cvs. Samira, Novita Plus, AF-2847, and Yasmin, either non-inoculated or infected with PRSV-W-1 and ZYMV-M, alone or mixed, in a plastic greenhouse.

\begin{tabular}{|c|c|c|c|c|c|}
\hline \multirow{2}{*}{ Treatment } & \multicolumn{2}{|c|}{ Fruit weight (kg per plant) } & \multirow{2}{*}{$\begin{array}{l}\text { Mean fruit weight } \\
\text { (kg per plant) }\end{array}$} & \multirow{2}{*}{$\begin{array}{l}\text { Mean rating of } \\
\text { fruit symptoms }\end{array}$} & \multirow{2}{*}{$\begin{array}{l}\text { Mean rating of } \\
\text { leaf symptoms }\end{array}$} \\
\hline & Total & Marketable & & & \\
\hline \multicolumn{6}{|c|}{ SAMIRA } \\
\hline Non-inoc. & $1.55 * \mathrm{a}$ & $1.36 \mathrm{a}$ & $0.24 \mathrm{a}$ & $1.0 \mathrm{a}$ & $1.0 \mathrm{a}$ \\
\hline ZYMV-M & $1.48 \mathrm{a}$ & $1.36 \mathrm{a}$ & $0.26 \mathrm{a}$ & $1.1 \mathrm{a}$ & $1.8 \mathrm{~b}$ \\
\hline PRSV-W-1 & $0.94 \mathrm{a}$ & $0.15 \mathrm{~b}$ & $0.21 \mathrm{a}$ & $3.1 \mathrm{c}$ & $4.0 \mathrm{c}$ \\
\hline Mixed & $1.24 \mathrm{a}$ & $0.24 \mathrm{~b}$ & $0.24 \mathrm{a}$ & $2.6 \mathrm{~b}$ & $3.8 \mathrm{c}$ \\
\hline \multicolumn{6}{|c|}{ NOVITA PLUS } \\
\hline Non-inoc. & $3.16 \mathrm{a}$ & $2.57 \mathrm{a}$ & $0.24 \mathrm{a}$ & $1.2 \mathrm{a}$ & $1.0 \mathrm{a}$ \\
\hline ZYMV-M & $2.78 \mathrm{a}$ & $2.18 \mathrm{a}$ & $0.23 \mathrm{ab}$ & $1.5 \mathrm{~b}$ & $1.8 \mathrm{~b}$ \\
\hline PRSV-W-1 & $2.10 \mathrm{a}$ & $0.30 \mathrm{~b}$ & $0.21 \mathrm{~b}$ & $3.0 \mathrm{c}$ & $4.2 \mathrm{c}$ \\
\hline Mixed & $2.19 \mathrm{a}$ & $0.53 \mathrm{~b}$ & $0.21 \mathrm{~b}$ & $2.9 \mathrm{c}$ & $4.4 \mathrm{c}$ \\
\hline \multicolumn{6}{|c|}{ AF-2847 } \\
\hline Non-inoc. & $2.39 \mathrm{a}$ & $2.07 \mathrm{a}$ & $0.25 \mathrm{a}$ & $1.1 \mathrm{a}$ & $1.0 \mathrm{a}$ \\
\hline ZYMV-M & $2.34 \mathrm{a}$ & $1.61 \mathrm{a}$ & $0.25 \mathrm{a}$ & $1.9 \mathrm{~b}$ & $1.6 \mathrm{~b}$ \\
\hline PRSV-W-1 & $2.03 \mathrm{a}$ & $0.71 \mathrm{~b}$ & $0.25 \mathrm{a}$ & $2.6 \mathrm{c}$ & $3.9 \mathrm{c}$ \\
\hline Mixed & $1.72 \mathrm{a}$ & $0.51 \mathrm{~b}$ & $0.23 \mathrm{a}$ & $2.6 \mathrm{c}$ & $4.3 \mathrm{c}$ \\
\hline \multicolumn{6}{|c|}{ YASMIN } \\
\hline Non-inoc. & $1.71 \mathrm{a}$ & $1.39 \mathrm{a}$ & $0.18 \mathrm{a}$ & $1.4 \mathrm{a}$ & $1.0 \mathrm{a}$ \\
\hline ZYMV-M & $2.10 \mathrm{a}$ & $1.35 \mathrm{a}$ & $0.17 \mathrm{a}$ & $2.1 \mathrm{~b}$ & $1.8 \mathrm{~b}$ \\
\hline PRSV-W-1 & $1.82 \mathrm{a}$ & $0.00 \mathrm{~b}$ & $0.18 \mathrm{a}$ & $3.5 \mathrm{c}$ & $3.5 \mathrm{c}$ \\
\hline Mixed & $1.70 \mathrm{a}$ & $0.13 \mathrm{~b}$ & $0.17 \mathrm{a}$ & $3.4 \mathrm{c}$ & $3.3 \mathrm{c}$ \\
\hline
\end{tabular}

*Means of each cultivar followed by the same letter in a column do not differ (Tukey's test at $p=0.05$ ). 
Table 2 - Weight of total fruits and marketable fruits per plant, mean fruit weight, mean rating of symptoms in fruits and leaves of zucchini squash cvs. Samira, Novita Plus, AF-2847, and Yasmin, either non-inoculated or infected with PRSV-W-1, in the field and plastic greenhouse.

\begin{tabular}{|c|c|c|c|c|c|}
\hline \multirow{2}{*}{ Treatment } & \multicolumn{2}{|c|}{ Fruit weight (kg per plant) } & \multirow{2}{*}{$\begin{array}{l}\text { Mean fruit weight } \\
\text { (kg per plant) }\end{array}$} & \multirow{2}{*}{$\begin{array}{l}\text { Mean rating of } \\
\text { fruit symptoms }\end{array}$} & \multirow{2}{*}{$\begin{array}{l}\text { Mean rating o } \\
\text { leaf symptoms }\end{array}$} \\
\hline & Total & Marketable & & & \\
\hline \multicolumn{6}{|c|}{ SAMIRA } \\
\hline Non-inoc. field & $1.45 * \mathrm{a}$ & $1.45 \mathrm{a}$ & $0.22 \mathrm{a}$ & $1.1 \mathrm{a}$ & $1.1 \mathrm{a}$ \\
\hline PRSV-W-1 field & $1.42 \mathrm{a}$ & $0.70 \mathrm{a}$ & $0.22 \mathrm{a}$ & $2.0 \mathrm{c}$ & $2.2 \mathrm{~b}$ \\
\hline Non-inoc. greenhouse & $1.76 \mathrm{a}$ & $1.59 \mathrm{a}$ & $0.27 \mathrm{a}$ & $1.0 \mathrm{a}$ & $1.0 \mathrm{a}$ \\
\hline PRSV-W-1 greenhouse & $1.10 \mathrm{a}$ & $0.74 \mathrm{a}$ & $0.21 \mathrm{a}$ & $1.8 \mathrm{~b}$ & $2.1 \mathrm{~b}$ \\
\hline \multicolumn{6}{|c|}{ NOVITA PLUS } \\
\hline Non-inoc. field & $1.49 \mathrm{ab}$ & $1.43 \mathrm{ab}$ & $0.20 \mathrm{a}$ & $1.2 \mathrm{a}$ & $1.2 \mathrm{a}$ \\
\hline PRSV-W-1 field & $1.79 \mathrm{a}$ & $1.70 \mathrm{a}$ & $0.22 \mathrm{a}$ & $1.2 \mathrm{a}$ & $2.3 \mathrm{~b}$ \\
\hline Non-inoc. greenhouse & $1.37 \mathrm{ab}$ & $1.24 \mathrm{ab}$ & $0.20 \mathrm{a}$ & $1.1 \mathrm{a}$ & $1.0 \mathrm{a}$ \\
\hline PRSV-W-1 greenhouse & $1.11 \mathrm{~b}$ & $1.05 \mathrm{~b}$ & $0.23 \mathrm{a}$ & $1.4 \mathrm{~b}$ & $2.0 \mathrm{~b}$ \\
\hline \multicolumn{6}{|c|}{ AF -2847} \\
\hline Non-inoc. field & $1.50 \mathrm{a}$ & $1.45 \mathrm{a}$ & $0.23 \mathrm{a}$ & $1.0 \mathrm{a}$ & $1.0 \mathrm{a}$ \\
\hline PRSV-W-1 field & $1.39 \mathrm{a}$ & $1.29 \mathrm{a}$ & $0.22 \mathrm{a}$ & $1.2 \mathrm{~b}$ & $2.0 \mathrm{~b}$ \\
\hline Non-inoc. greenhouse & $1.56 \mathrm{a}$ & $1.46 \mathrm{a}$ & $0.24 \mathrm{a}$ & $1.0 \mathrm{a}$ & $1.0 \mathrm{a}$ \\
\hline PRSV-W-1 greenhouse & $1.21 \mathrm{a}$ & $1.09 \mathrm{a}$ & $0.24 \mathrm{a}$ & $1.2 \mathrm{~b}$ & $2.0 \mathrm{~b}$ \\
\hline \multicolumn{6}{|c|}{ YASMIN } \\
\hline Non-inoc. field & $0.90 \mathrm{a}$ & $0.88 \mathrm{a}$ & $0.16 \mathrm{a}$ & $1.0 \mathrm{a}$ & $1.1 \mathrm{a}$ \\
\hline PRSV-W-1 field & $1.02 \mathrm{a}$ & $0.96 \mathrm{a}$ & $0.18 \mathrm{a}$ & $1.2 \mathrm{a}$ & $2.1 \mathrm{~b}$ \\
\hline Non-inoc. greenhouse & $1.03 \mathrm{a}$ & $0.81 \mathrm{a}$ & $0.18 \mathrm{a}$ & $1.1 \mathrm{a}$ & $1.0 \mathrm{a}$ \\
\hline PRSV-W-1 greenhouse & $0.78 \mathrm{a}$ & $0.31 \mathrm{~b}$ & $0.16 \mathrm{a}$ & $2.3 \mathrm{~b}$ & $2.0 \mathrm{~b}$ \\
\hline
\end{tabular}

* Means of each cultivar followed by the same letter in a column do not differ (Tukey's test at $p=0.05$ ).

Preimmunization with mild strains of PRSVW has already been successfully tested in Brazil in zucchini squash cv. Caserta under field conditions (Rezende \& Pacheco, 1998), and showed that preimmunized plants yielded an average of $13.5 \%$ of unmarketable fruits, against $75.5 \%$ from naturally infected unprotected plants. Yield evaluation of zucchini squash Caserta preimmunized with mild strains PRSVW-1 and ZYMV-M, in 2001, resulted in $15.3 \%$ of unmarketable fruits, but no intensification of leaf symptoms was observed in the plants (data not published). In the present study, however, results of the first assay, which was developed in plastic greenhouses, were not similar to those mentioned above, especially with regard to the quality of fruits harvested from plants infected with PRSV-W-1 alone or together with ZYMV$M$. Although no pronounced alterations in weight and skin texture were observed in the harvested fruits, their quality was quite affected. Symptoms were mainly characterized by skin color intensification causing these fruits to be classified as unmarketable (Figure 1).

In Taiwan, the production of unmarketable fruits of zucchini squash plants preimmunized with the mild strain ZYMV-WK, for two independent experi- ments, was $8.9 \%$ and $13.5 \%$, respectively. The yield of unmarketable fruits in non-protected infected plants was $18 \%$ and $69 \%$, respectively (Wang et al., 1991). In the UK, the yield of courgette and marrow plants protected with ZYMV-WK was evaluated but there is not reference to any affect of the mild strain on the quality of the fruits (Spence et al., 1996). In California, studied on the protection of 'TopMark' melon plants with ZYMV-WK showed that $75 \%$ of total fruit yielded was classified as marketable (Perring et al., 1995). In Brazil, $16.2 \%$ of fruits harvested from Tetsukabuto (Takayama) hybrid pumpkin plants infected with mild strain PRSV-W-1 were unmarketable (Dias \& Rezende, 2000).

Leaf symptoms and skin alterations in the four cultivars infected with PRSV-W-1 do not seem to be associated with strain changes, but probably with the sensitivity of the tested cultivar or environmental factors (luminosity, temperature, or other). This hypothesis is supported by a mild strain recovery test, in which leaf extracts of 12 PRSV-W-1 infected plants (three of each cultivar) showing marked leaf symptoms were mechanically inoculated into zucchini squash plants cv. Caserta under greenhouse conditions. 

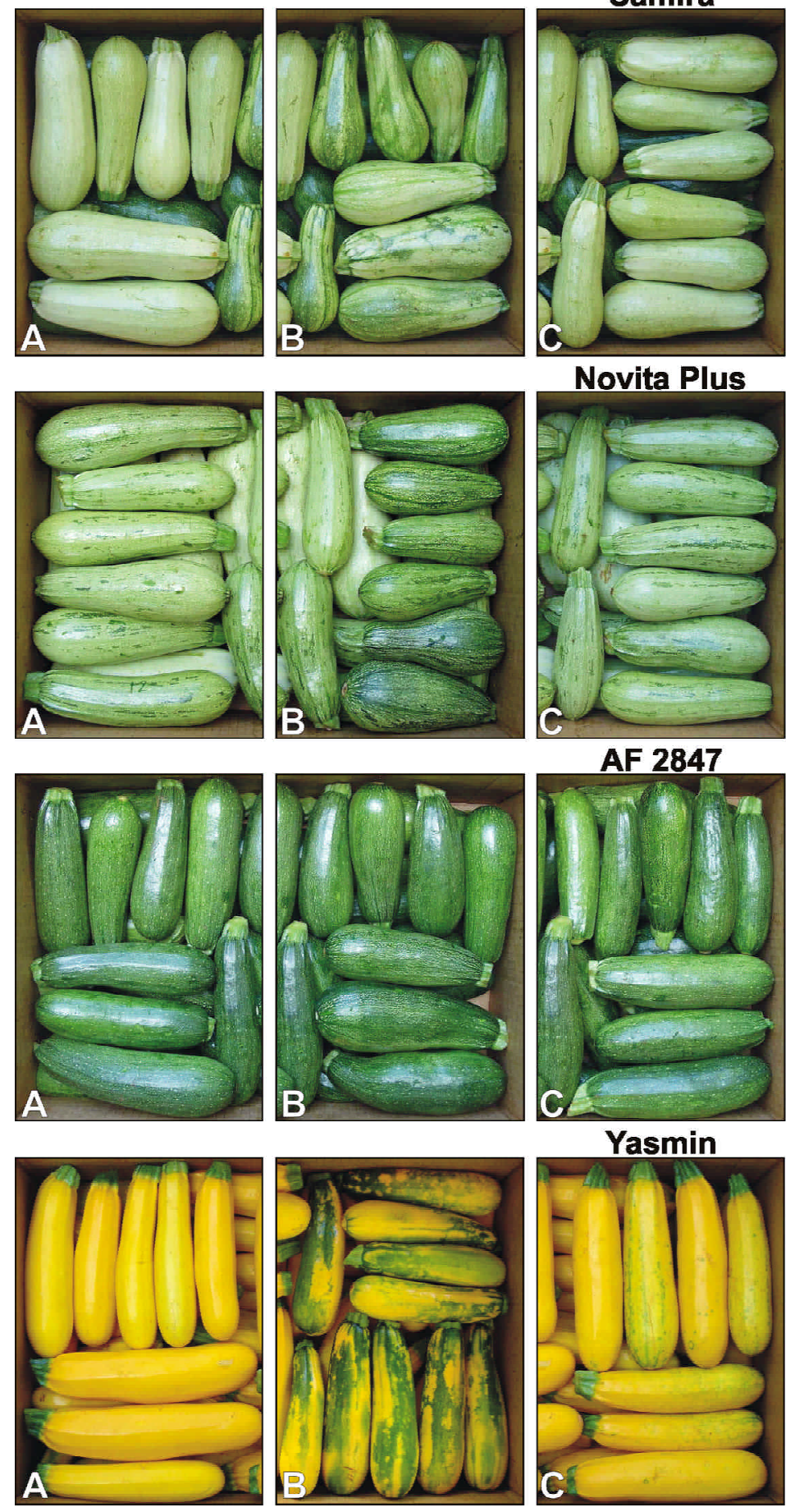
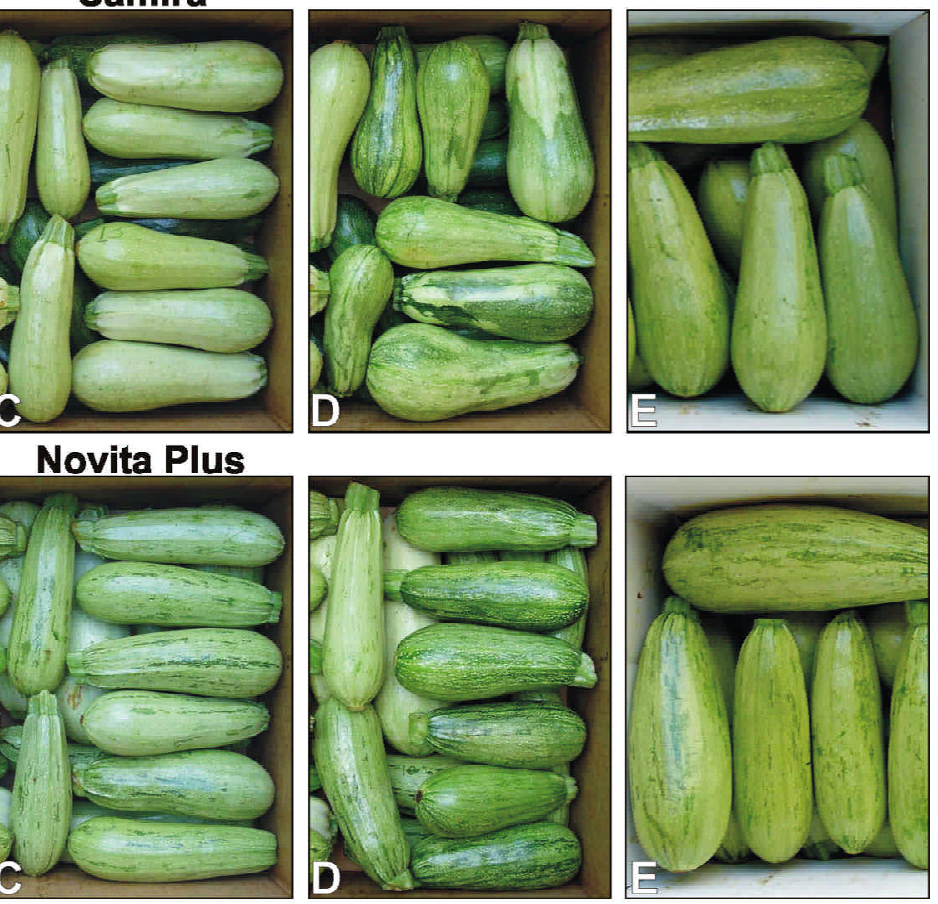

\section{AF 2847}
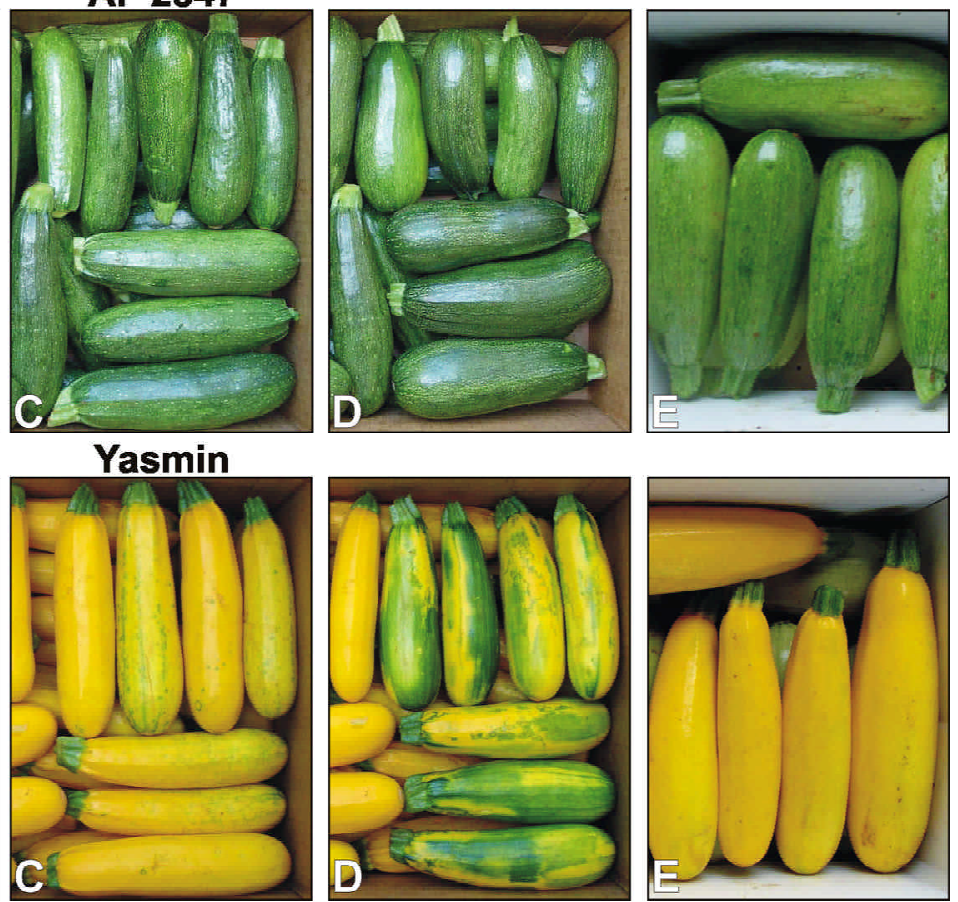

Figure 1 - Fruits of cvs. Samira, Novita Plus, AF 2847, and Yasmin harvested from non-inoculated plants (A); infected with PRSV-W1 (B), infected with ZYMV-M (C), and infected with both (D) in an assay conducted in a plastic greenhouse; and plants infected with PRSV-W-1 in a field assay (E).

An extract from the original source of PRSV-W-1 was used as a control. Only one plant exhibited severe mosaic symptoms after twenty days of observation. Confirmation of mild strain infection in all test-plants was done by PTA-ELISA (data not presented).

Despite these results, double preimmunization still seems to be a viable alternative for controlling both viral diseases in susceptible zucchini squash cultivars, since most crops are grown in open field and not in plastic greenhouses, where symptom intensification was more pronounced. In addition, even varieties that demonstrated greater sensitivity to PRSV-W-1 infection showed a good production of marketable fruits, which probably would not occur if those plants were 
infected with severe PRSV-W and ZYMV strains, which might cause yield damages of 100\% (Pereira et al., 2007).

\section{ACKNOWLEDGMENTS}

This research was funded by FAPESP (Fundação de Amparo à Pesquisa do Estado de São Paulo). The authors would like to thank Dr. Hugo Kuniyuki (APTA, IAC, Campinas, SP) for critically reading the manuscript.

\section{REFERENCES}

DESBIEZ, C.; LECOQ, H. Zucchini yellow mosaic virus. Plant Pathology, v.46, p.809-829, 1997.

DIAS, P.R.P.; REZENDE, J.A.M. Premunização da abóbora híbrida Tetsukabuto para o controle do mosaico causado pelo Papaya ringspot virus - type W. Summa Phytopathologica, v.26, p.390-398, 2000.

MOWAT, W.P.; DAWSON, S. Detection of plant viruses by ELISA using crude sap extracts unfractionated antisera. Journal of Virological Methods, v.15, p.233-247, 1987.

PEREIRA, M.J.Z.; SUSSEL, A.A.B.; SILVA, R.F.; KUHN, O.J.; DOMINGUES, F.; REZENDE, J.A.M. Danos na produção da abobrinha de moita causados pelo Papaya ringspot virus - type W e Zucchini yellow mosaic virus. Summa Phytopathologica, v.33, p. 192-194, 2007.

PERRING, T.M.; FARRAR, C.A.; BLUA, M.J.; WANG, H.L.; GONSALVES, D. Cross protection of cantaloupe with a mild strain of zucchini yellow mosaic virus: effectiveness and application. Crop Protection, v.14, p.601-606, 1995.
PURCIFULL, D.; EDWARDSON, J.; HIEBERT, E.; GONSALVES, D. Papaya ringspot virus. Kew: CMI/AAB, 1984. 8p. (CMI/ AAB Descriptions of Plant Viruses, 292).

RABELO, L.C.; REZENDE, J.A.M. Seleção de uma estirpe fraca do Zucchini yellow mosaic virus com potencial para uso na premunização. Summa Phytopathologica, v.30, p.340-345, 2004.

REZENDE, J.A.M.; PACHECO, D.A. Control of Papaya ringspot virus-Type $\mathrm{W}$ in zucchini squash by cross-protection in Brazil. Plant Disease, v.82, p.171-175, 1998.

REZENDE, J.A.M.; PACHECO, D.A.; IEMMA, A.F. Efeitos da premunização da abóbora 'Menina Brasileira' com estirpes fracas do vírus-do-mosaico-do-mamoeiro-estirpe melancia. Pesquisa Agropecuária Brasileira, v.34, p.141-148, 1999.

REZENDE, J.A.M.; YUKI, V.A.; VEGA, J.; SCAGLIUSI, S.M.M.; BORBA, L.F.; COSTA, A.S. Isolados fracos do potyvirus causador do mosaico da abobrinha presentes em bolhas atuam na premunização. Fitopatologia Brasileira, v.19, p.55-61, 1994.

SPENCE, N.J.; MEAD, A.; MILLER, A.; SHAW, E.D.; WALKEY, D.G.A. The effect on yield in courgette and marrow of the mild strain of zucchini yellow mosaic virus used for cross-protection. Annals of Applied Biology, v.129, p.247-259, 1996.

WANG, H.L.; GONSALVES, D.; PROVVIDENTI, R.; LECOQ, H.L. Effectiveness of cross protection by mild strain of Zucchini yellow mosaic virus in cucumber, melon and squash. Plant Disease, v. 75, p.203-207, 1991.

Received December 06, 2007

Accepted November 14, 2008 